\title{
Ghrelin Peptide Analogue
}

National Cancer Institute

\section{Source}

National Cancer Institute. Ghrelin Peptide Analogue. NCI Thesaurus. Code C84868.

A ghrelin peptide analogue with potential anti-cachexia activity. Upon subcutaneous administration, ghrelin peptide analogue binds to and stimulates the G protein-coupled growth hormone secretag ogue receptor (GHSR) in the central nervous system (CNS), thereby mimicking the appetite-stimulating and growth hormone-releasing effects of endogenous ghrelin. Stimulation of GHSR may also reduce the production of the proinflammatory cytokines TNF-alpha and interleukin-6, which may play direct roles in cancer-related loss of appetite. Ghrelin, naturally secreted by gastric endocrine cells, is a 28 amino acid peptide and an endogenous lig and for GHSR. 